\title{
Bis(4-hydroxy-2H-chromen-2-one) Coumarin Induces Apoptosis in MCF-7 Human Breast Cancer Cells Through Aromatase Inhibition
}

\author{
LAMIA HAMDAN RAMDANI ${ }^{1,2}$, OUALID TALHI ${ }^{1,3}$, CAROLINE DECOMBAT $^{2}$, \\ MARION VERMERIE ${ }^{2}$, ALEXANDRE BERRY $^{2}$, ARTUR SILVA $^{3}$, KHALDOUN BACHARI $^{1}$, \\ MARIE-PAULE VASSON ${ }^{2,4}$, LAETITIA DELORT $^{2 *}$ and FLORENCE CALDEFIE-CHÉZET ${ }^{2,5^{*}}$ \\ ${ }^{1}$ Scientific and Technical Research Center in Physico-Chemical Analysis (CRAPC), Tipaza, Algeria; \\ ${ }^{2}$ Clermont Auvergne University, INRA, UNH, Human Nutrition unit, CRNH Auvergne, Clermont Ferrand, France; \\ ${ }^{3}$ Organic Chemistry, Natural Products and Agrifood (QOPNA), \\ Department of Chemistry \& QOPNA, University of Aveiro, Aveiro, Portugal; \\ ${ }^{4}$ Anticancer Center Jean-Perrin, Clermont Ferrand, France; \\ ${ }^{5}$ CLARA, Lyon Auvergne Rhone Alpes canceropole, Lyon, France
}

\begin{abstract}
Aim: The present investigation aimed to examine the therapeutic potential of the new coumarin derivative bis(4-hydroxy-2H-chromen-2-one) coumarin (4HC) against breast cancer. Materials and Methods: For this purpose, the effects of $4 H C$ treatment on the proliferation of MCF-7 breast cancer cells and on MCF-10a non-cancerous cells were evaluated using a fluorescent assay. Cell cycle distribution and apoptosis were measured by image cytometry. The expression level of aromatase (CYP19A1) and apoptosis-related genes were determined by real-time PCR. Results: MCF-7 mammary cancer cell proliferation was significantly decreased within $24 \mathrm{~h}$ after treatment with $4 H C$ at $50 \mu \mathrm{M}$, while no effect was observed on the viability of MCF-10a non-cancerous mammary cells. 4HC also increased the percentage of the cells in the G2/M phase, inducing apoptosis. Real-time PCR revealed that $4 H C$ induced MCF-7 mortality through an up-regulation of Bax and a down-regulation of Bcl-2, resulting in an increase in caspase-3 gene expression. The increased expression of apoptosis-related genes was accompanied by a decrease in
\end{abstract}

\footnotetext{
*These Authors contributed equally to this work.

Correspondence to: Lamia Hamdan Ramdani, Clermont Auvergne University, INRA, UNH, Human Nutrition Unit, CRNH Auvergne, F-63000 Clermont-Ferrand, France. Tel: +213 799423134, e-mail: lamia_pharm@yahoo.fr
}

Key Words: Coumarin derivative, Bis(4-hydroxy-2H-chromen-2one), breast cancer, cell proliferation, cell cycle, apoptosis, aromatase inhibition, MCF-7 breast cancer cells.
CYP19A1 gene expression. Conclusion: 4HC selectively inhibits proliferation of MCF-7cells in vitro. Moreover, $4 H C$ has inhibitory effects on aromatase gene expression and promoting effects on apoptosis, in MCF-7 cells.

Breast cancer is the first cause of cancer-related mortality in women worldwide. Unfortunately, current chemotherapy is responsible for several side-effects and the urgency of development of new anticancer agents to improve treatment of breast cancer, without affecting normal cells, is imperative (1). Coumarins are naturally occurring constituents of many plants and essential oils such as Tonka beans, sweet clover, woodruff, oil of cassia, and lavender (2). Natural and synthetic coumarin derivatives are recognized as important active compounds with beneficial effects on human health including anticoagulant, vasoprotector, antioxidant, antiinflammatory and antimicrobial activities (3).

In recent years, a significant number of coumarin derivatives have been studied as potential agents for cancer therapy (4), particularly in breast cancer (5). Depending on their structure, they can inhibit tumor necrosis factor-alpha $(\mathrm{TNF} \alpha)$ production, cell cycle and aromatase activities or induce apoptosis through the activation of caspases $(6,7)$. Special attention has been devoted to the new synthetic bis(4-hydroxy-2H-chromen-2one) coumarin, named 4HC, which has been reported to inhibit proliferation and to promote cell death in tumor cell lines (8).

Based on the diverse biological activity reported by coumarin derivatives, the anti-tumor potential and proapoptotic activities of $4 \mathrm{HC}$ have been investigated in MCF7 estrogen receptor-positive $\left(\mathrm{ER}^{+}\right)$breast cancer cells, a widely-used model system for the study of breast cancer (9). 
The induction of apoptosis in tumor cells is an important regulated process tightly involved in therapy and the prevention of cancer.

The impact of $4 \mathrm{HC}$ on aromatase activity has also been evaluated. Indeed, breast cancer is known to be under hormonal control and the inhibition of estrogen synthesis by aromatase inhibitors results in the reduction of breast cancer cell proliferation and the induction of apoptosis (10). Several studies reported that coumarin derivatives could be potential aromatase inhibitors and highlighted their efficiency for breast cancer therapy (11). Based on all the above, the expression of aromatase (CYP19A1 gene) was quantified in order to provide insight into the mechanism of the proapoptotic effects of $4 \mathrm{HC}$. Finally, we demonstrated that $4 \mathrm{HC}$ could be considered as a novel chemotherapeutic agent for breast cancer.

\section{Materials and Methods}

Chemistry. Synthesis of bis (4-hydroxy-2H-chromen-2-one) coumarin, namely $4 \mathrm{HC}$, was performed according to the previously described method (8) (Figure 1). Structural identification of 4HC was elucidated by extensive one-dimensional (1D) and twodimensional (2D) nuclear magnetic resonance (NMR) techniques. The stock solutions $(10 \mathrm{mM})$ of $4 \mathrm{HC}$ were dissolved in DMSO, preserved at $-4^{\circ} \mathrm{C}$ and diluted in a culture medium to realize the experiments.

Cell culture. The human breast cancer cell line MCF-7 and the human non-tumorigenic epithelial cell line MCF-10a were obtained from the American Type Culture Collection (Molsheim, France). MCF-7 cells were cultured in RPMI-1640 (GIBCO, Invitrogen, Carlsbad, CA, USA) containing $10 \%$ heat inactivated fetal bovine serum (FBS) (Eurobio, Courtaboeuf, France), 1\% L-glutamine (2 mM) (GIBCO), $0.5 \%$ gentamycin $(50 \mathrm{mg} / \mathrm{ml})$ (Fisher Scientific, Strasbourg, France) and $0.04 \mathrm{UI} / \mathrm{ml}$ of insulin (Sigma-Aldrich, Saint-Quentin-Fallavier, France). MCF-10a cells were cultured in DMEM/F-12 medium (GIBCO) supplemented with $10 \%$ heat-inactivated horse serum (Pan Biotech, France), EGF $(0.02 \mu \mathrm{g} / \mathrm{ml})$, hydrocortisone $(0.5 \mu \mathrm{g} / \mathrm{ml})$, insulin $(0.25 \mathrm{UI} / \mathrm{ml})$ and cholera toxin $(0.1 \mu \mathrm{g} / \mathrm{ml})$ (Sigma-Aldrich). All cells were kept at $37^{\circ} \mathrm{C}$ under a $5 \% \mathrm{CO}_{2}$ atmosphere.

Cell proliferation analysis by resazurin assay. Human breast cancer cells MCF-7 and non-cancerous mammary cells MCF-10a were seeded in 96 -well plates $\left(1 \times 10^{4} /\right.$ well $)$ in complete media $24 \mathrm{~h}$ before treatment with $4 \mathrm{HC} .4 \mathrm{HC}$ was added at concentrations ranging from 0 to $100 \mu \mathrm{M}$ for 24,48 , and $72 \mathrm{~h}$. At the end of the treatment, 200 $\mu \mathrm{l}$ of a $25 \mu \mathrm{g} / \mathrm{ml}$ solution of resazurin (Sigma-Aldrich) was added to each well for $2 \mathrm{~h}$ of incubation at $37^{\circ} \mathrm{C}$. Control wells received the vehicle solvent $(0.1 \% \mathrm{v} / \mathrm{v}$ DMSO $)$ and doxorubicin $(1 \mu \mathrm{M})$ was used as a positive control. Fluorescence was measured on an automated 96-well plate reader (Fluoroskan Ascent FL, Thermo Fisher Scientific, Wilmington, DE, USA) and data were normalized to the control group fluorescence.

Cell cycle analysis. MCF-7 cells were seeded into 12-well plates $\left(1 \times 10^{5}\right.$ cells/well) for $24 \mathrm{~h}$ and synchronized by arresting the cells in the $\mathrm{G}_{0}$ phase, through serum deprivation for an additional $24 \mathrm{~h}$.
Table I. Primer sequences.

\begin{tabular}{ll}
\hline Genes & Primer sequences \\
\hline CYP19A1 & F: GAA TAT TGG AAG GAT GCA CAG ACT \\
& R: GGG TAA AGA TCA TTT CCA GCA TGT \\
Bax & F: TGCTTCAGGGTTCATCCAG \\
Bcl-2 & R: GGCGGCAATCATCCTCTG \\
Faspase 3 & R: GGCTGGGATGCCTTTGTG \\
GAPDH & F: ACATGGCGTGTCATAAAATACC \\
& F: CACAAAGCGACTGGATGAAC \\
& R: TGAGGGTCTCTCTCTTCCTCTTGT \\
\hline
\end{tabular}

F, Forward; R, reverse.

Cells were then treated for $72 \mathrm{~h}$ with $4 \mathrm{HC}(0,25 \mu \mathrm{M}$ or $50 \mu \mathrm{M})$. After trypsinization and centrifugation, cell pellets were resuspended in $200 \mu \mathrm{l}$ of PBS for a final concentration of $5 \times 10^{6}$ cells $/ \mathrm{ml}$. After storage at $-20^{\circ} \mathrm{C}$, cells were centrifuged and stained with $50 \mu \mathrm{g} / \mathrm{ml}$ of propidium iodide (PI) (Sigma-Aldrich) and 100 $\mu \mathrm{g} / \mathrm{ml}$ of ribonuclease A (Sigma-Aldrich). After incubation, cells were analyzed using Cellometer Vision K2 (Nexcelom Bioscience, Lawrence, MA, USA). Data were analyzed using the FCS express 6 image Cytometry software (De Novo software). Experiments were repeated in triplicate.

Apoptosis detection by Annexin V-FITC/PI staining. Apoptotic cells were quantified by Annexin V-FITC/PI (Sigma-Aldrich) staining according to the manufacturer's protocol. In brief, cells in a 12-well plate were treated with $4 \mathrm{HC}$ at a concentration of $100 \mu \mathrm{M}$ for $72 \mathrm{~h}$. Then cells were washed with PBS, harvested with trypsin and suspended in $50 \mu \mathrm{l}$ of Annexin V Binding Buffer. Protected from light, Annexin V-FITC conjugate and PI were added to cells. After $15 \mathrm{~min}$ of incubation at room temperature, fluorescence of the cells was read immediately using image cytometer (Cellometer Vision K2, Nexcelom Bioscience, Lawrence, MA, USA). Data were analyzed using the FCS express 6 image Cytometry software (De Novo software). Experiments were repeated in triplicate.

Total RNA extraction. RNA extraction was performed using trizol (Sigma Aldrich). MCF-7 cells were seeded in a 12 -well plate $\left(1 \times 10^{5}\right.$ cells/well) and were treated with $4 \mathrm{HC}$ at a concentration of 50 and $100 \mu \mathrm{M}$ or with vehicle for $72 \mathrm{~h}$. After treatment, trizol was added in each well for total cell lysis. The mixture was separated by chloroform in three phases and RNA was collected in the aqueous phase. The RNA was precipitated with isopropanol then were frozen overnight at $-20^{\circ} \mathrm{C}$. Centrifugation at $12,000 \times \mathrm{g}$ for $15 \mathrm{~min}$ allowed recovering RNA pellets, which were washed with $70 \% \mathrm{EtOH}$. After a second centrifugation, the supernatants were carefully removed and samples were suspended in DEPC-treated water. The RNA concentration and purity was determined using a spectrophotometer (Nanodrop 2000; Thermo Scientific).

Real-time polymerase chain reaction $(q P C R)$. After a DNase treatment (DNase I Amplification grade, Invitrogen), $1 \mu \mathrm{g}$ of RNA was used to synthesis cDNA (HighCap cDNA RT Kit with RNAse inhibitor, Invitrogen) following the manufacturer's protocol. The 


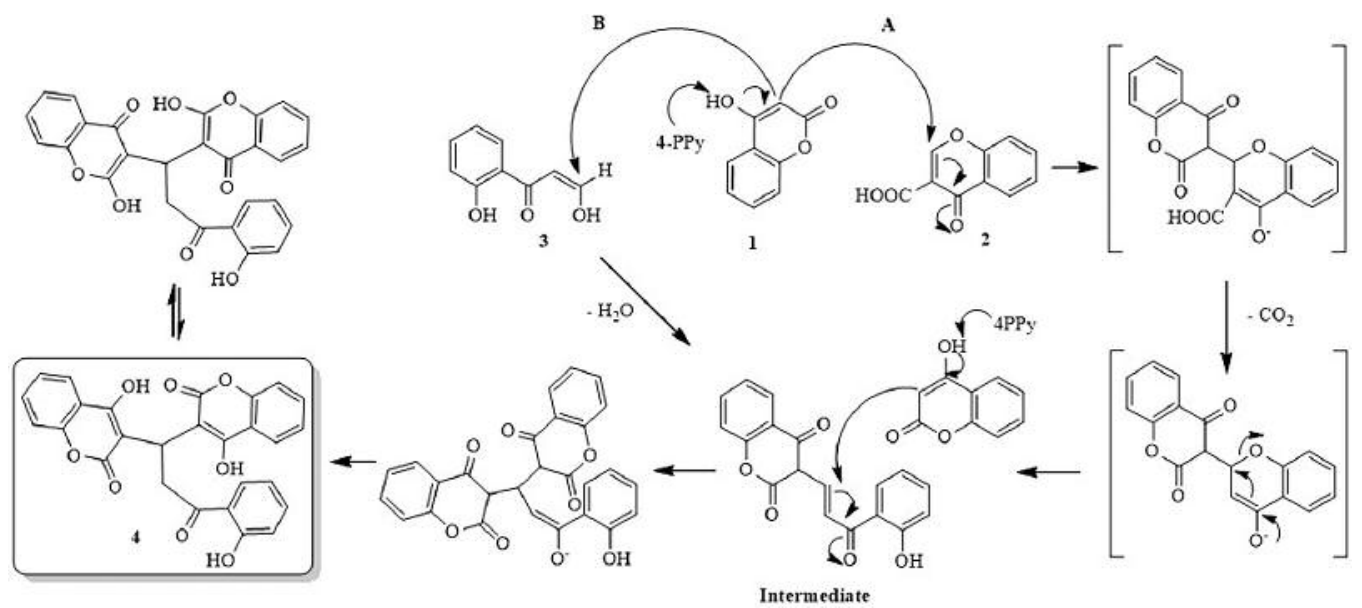

Figure 1. Synthesis of bis(4-hydroxy-2H-chromen-2-one) coumarin (4HC).

A

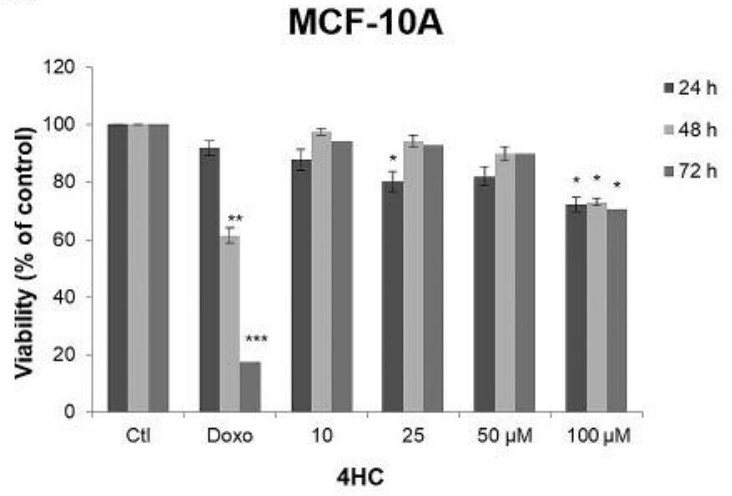

B

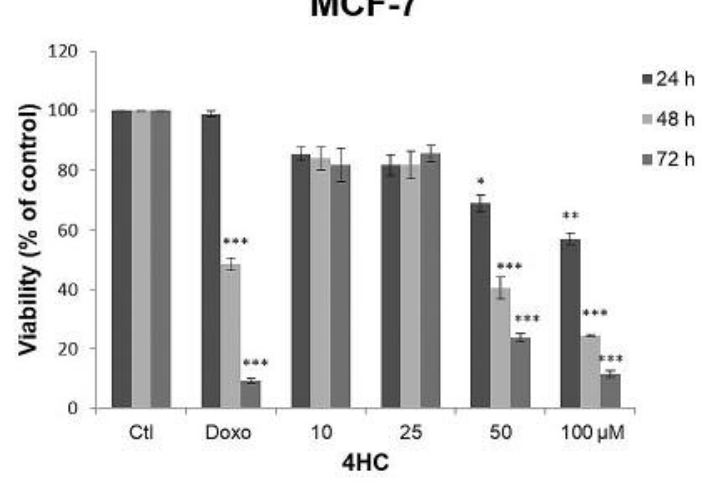

Figure 2. Proliferation of MCF-10a mammary non-cancerous cells (A) and MCF-7 mammary cancer cells (B) treated with 4 HC. 4 HC showed significant anti-proliferative activities in MCF-7 cells in time and concentration-dependent manner. $* p \leq 0.05 ; * * p \leq 0.01 ; * * * p \leq 0.001$ compared to the control value. Experiments were repeated in triplicate. Ctl, Control; Doxo, doxorubicin.

expressions of Bax, Bcl-2, Caspase 3 and CYP19Al were evaluated by real-time $\mathrm{qPCR}$. The reverse-transcribed products $(2 \mu \mathrm{l})$ were added to the PCR mixture $(18 \mu \mathrm{l})$ for 40 cycles. Each cycle included 15 seconds at $95^{\circ} \mathrm{C}$ and $1 \mathrm{~min}$ at $60^{\circ} \mathrm{C}$. Gene-specific primers are listed in Table I. GAPDH mRNA level was used for normalization. The relative quantification method $(\mathrm{RQ}=2-\Delta \Delta \mathrm{CT})$ was used to calculate the relative gene expression of given samples with $\Delta \Delta \mathrm{CT}=[\Delta \mathrm{CT}$ (sample1) $-\Delta \mathrm{CT}($ sample2) $]$ and $\Delta \mathrm{CT}=[\mathrm{CT}($ target gene) $-\mathrm{CT}$ (reference gene)].

Data analysis. Data were expressed as the mean \pm standard deviation (SD) and represented at least three independent experiments. Statistical analysis and significance were measured by the Student's t-test using SPSS software version 23.0. Differences at $p \leq 0.05$ (flagged as *) or $p \leq 0.01$ (flagged as **) or $p \leq 0.001$ (flagged as ***) were considered statistically significant.

\section{Results}

$4 H C$ inhibited breast cancer cell proliferation. In order to investigate the antiproliferative characteristics of $4 \mathrm{HC}, \mathrm{MCF}-$ 7 breast cancer cells and MCF-10a non-cancerous mammary cells were treated with increasing concentrations of $4 \mathrm{HC}$ for 24,48 , and $72 \mathrm{~h}$ and cell viability was measured as previously described. Results showed that concentrations up to $50 \mu \mathrm{M}$ of $4 \mathrm{HC}$ did not affect the viability of noncancerous mammary cells MCF-10a, while a slight decrease was observed at $100 \mu \mathrm{M}$ of treatment (Figure 2A). On the contrary, 4HC significantly decreased the proliferation of MCF-7 breast cancer cells in a dose and time dependent manner $(76.15 \%$ and $88.46 \%$ inhibition at $50 \mu \mathrm{m}$ and 100 

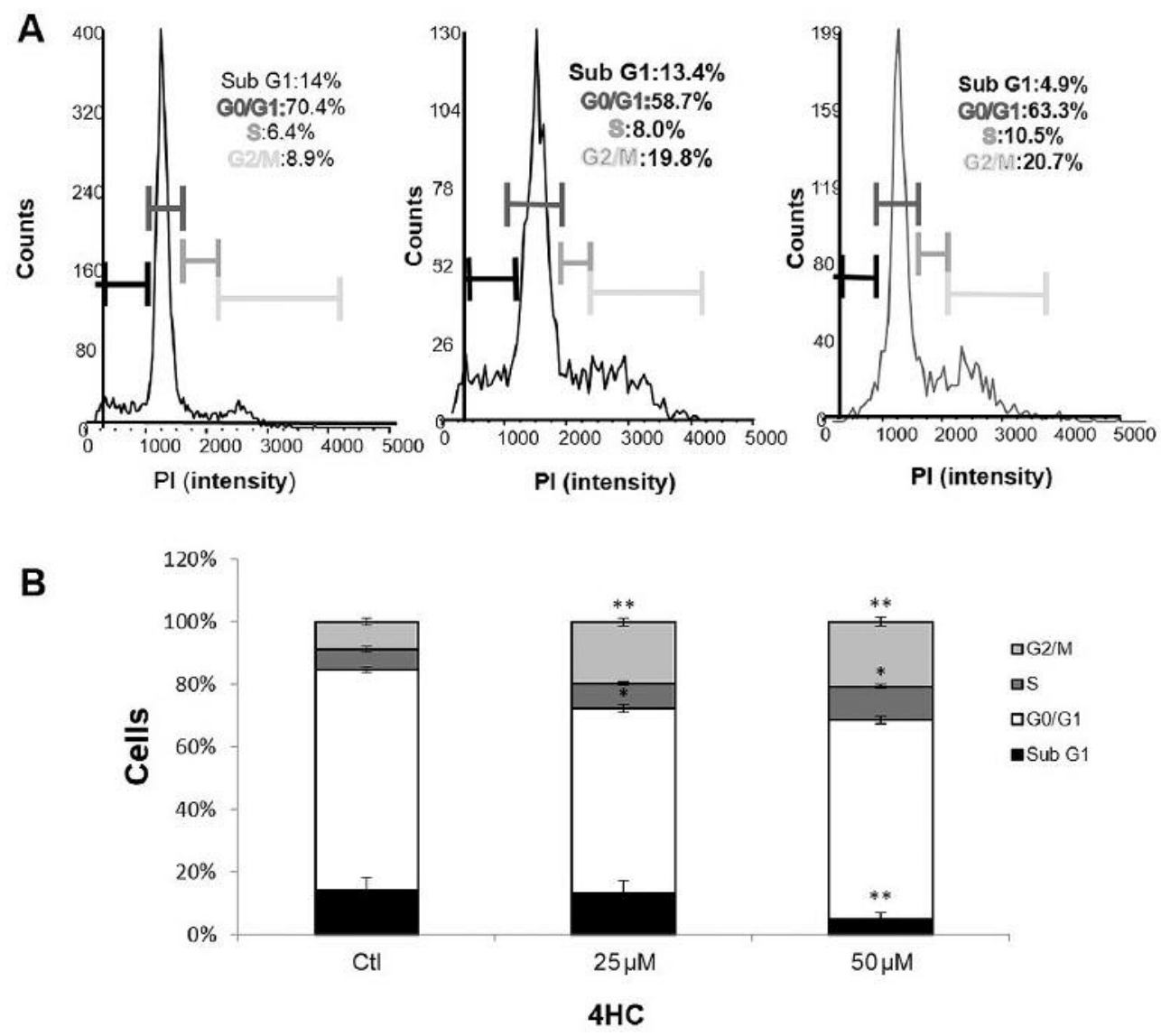

Figure 3. MCF-7 cell cycle distribution analysis (A). The percentage of cells in the $G_{1}, S$, and $G_{2} / M$ phases of the cell cycle are shown, following a treatment with 25 and $50 \mu M$ of $4 H C$ for $72 h(B) . * p \leq 0.05 ; * p \leq 0.01$ compared to the control group. Experiments were repeated in triplicate. PI, Propidium iodide; $c t l$, control.

$\mu \mathrm{m}$, respectively, after $72 \mathrm{~h}$ of treatment; $p \leq 0.001$, compared to the control group) (Figure 2B). In addition, the sensitivity of MCF-7 cells exposed at $100 \mu \mathrm{M}$ of $4 \mathrm{HC}$ was similar to that observed with the doxorubicin treatment $(88.46 \%$ of inhibition with $4 \mathrm{HC}$ at $100 \mu \mathrm{M}$ and $90.73 \%$ of inhibition with doxorubicine, compared to the control, $p \leq 0.001$ ).

$4 H C$ induced cell cycle arrest in $G_{2} / M$ phase. In order to demonstrate that the growth inhibition of MCF-7 cells induced by $4 \mathrm{HC}$ could be associated to cell cycle arrest, we analyzed cell cycle progression using the Cellometer K2 Fluorescent Cell Viability Counter (Figure 3A). MCF-7 cells were treated with 0,25 and $50 \mu \mathrm{M}$ of $4 \mathrm{HC}$ for $72 \mathrm{~h}$. As shown in (Figure 3B), the percentage of cells in the $\mathrm{G}_{2} / \mathrm{M}$ phase significantly increased from $8 \pm 0.98 \%$ (control condition) to $19 \pm 1.3 \% \quad(p<0.01)$ and $20 \pm 1.5 \% \quad(p<0.01)$ when cells were treated with 25 and $50 \mu \mathrm{M}$ of $4 \mathrm{HC}$, respectively. These results were accompanied by a decrease in the Sub $G_{1}$ phase distribution (from $14 \%$ in the control group to $4.9 \%$ in the $50 \mu \mathrm{M} 4 \mathrm{HC}$-treated group, $p \leq 0.01$ ).
$4 H C$ significantly promoted apoptosis in MCF-7 cells. To characterize cell death and assess the pro-apoptotic activity induced by $4 \mathrm{HC}$ in MCF-7 cells, we performed PI-annexin$\mathrm{V}$ double staining assays. The results demonstrated a significant increase in the late apoptosis rate in MCF-7 cells after $72 \mathrm{~h}$ of treatment with $100 \mu \mathrm{M}$ of $4 \mathrm{HC}$, compared to the control group $(58.75 \pm 2.55 \%$ and $8.55 \%$ respectively, $p \leq 0.01$; Figures $4 \mathrm{~A}$ and $4 \mathrm{~B}$ ).

Activation of the pro-apoptotic genes Bax and Caspase 3 and down-regulation of $\mathrm{BCl}-2$ were associated with the inhibition of CYP19A1. We performed q-RT-PCR to explore the probable mechanism whereby $4 \mathrm{HC}$ induced apoptosis. Analysis revealed (Figure 5) that $4 \mathrm{HC}$ treatment induced a significant decrease of CYP19Al gene expression $(0.37 \pm 0.1$ fold; $p \leq 0.05$, compared to the control group), accompanied by a significant up-regulation of pro-apoptotic genes when the concentration of $4 \mathrm{HC}$ was equal to $100 \mu \mathrm{M}$ (Bax: 3.65 $\pm 0,39$-fold; Caspase 3: 5.13 \pm 0.41 -fold; all $p$-values were $\leq 0.05$, compared to the control groups), and a significant 
A
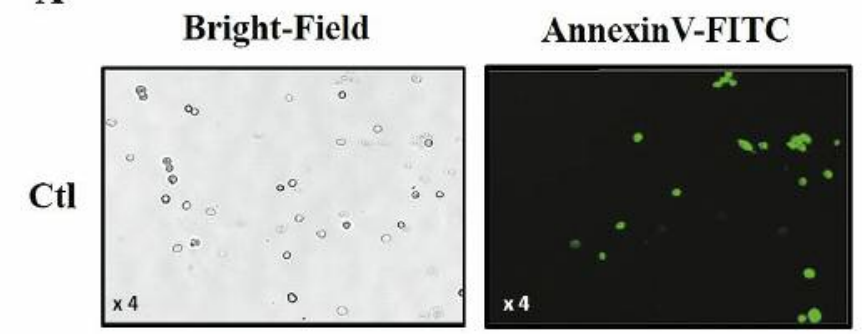

Propidium Iodide
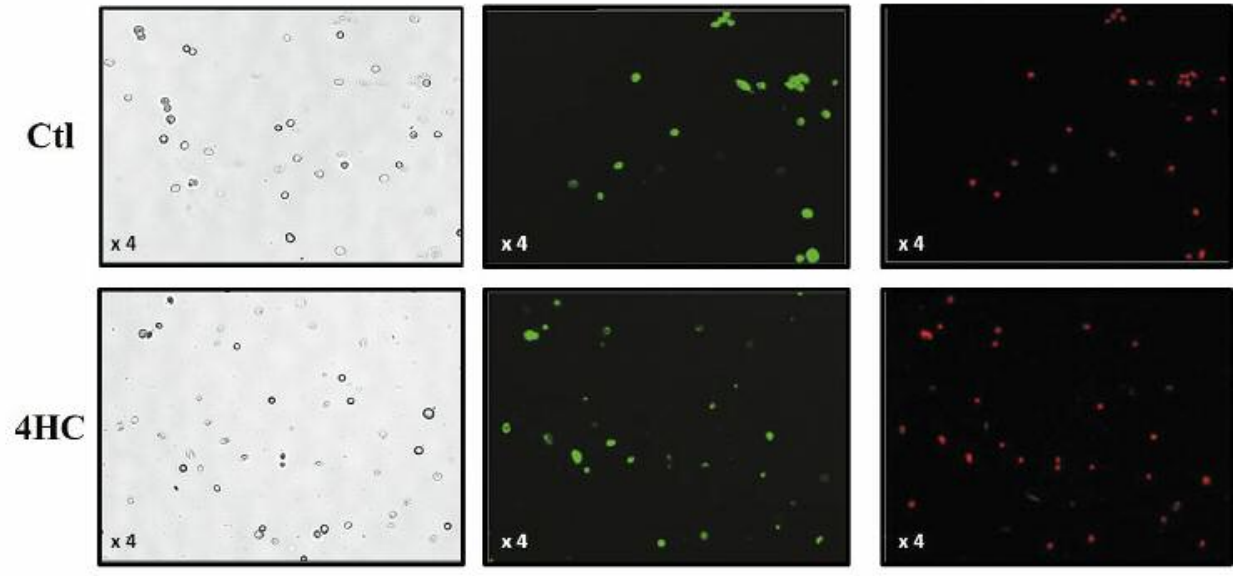

B

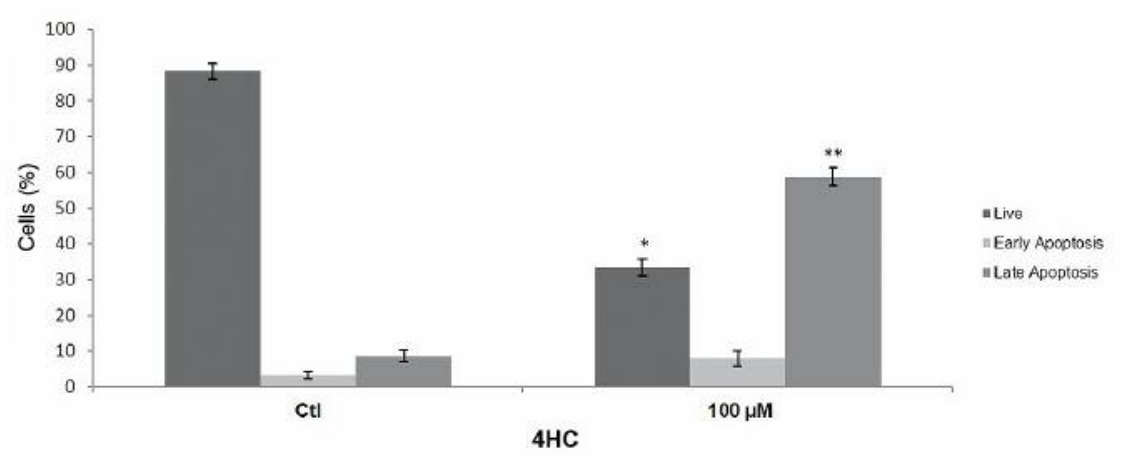

Figure 4. Evaluation of apoptosis in MCF-7 cells treated with 4HC. Images (captured by FCS express 6 image Cytometry, De Novo software) showed apoptosis in MCF-7 cells. Control and 4HC-treated cells for $72 \mathrm{~h}$ were stained with Annexin V-FITC and PI. (FITC-/PI-) reflected living cells, fluorescence (FITC+/PI-) represented early apoptotic cells, and fluorescence (FITC+/PI+) showed late apoptotic cells (A). The percentage of apoptosis is represented as the mean $\pm S D(B) . * p \leq 0.05 ; * * \leq 0.01$, compared to the control. Experiments were repeated in triplicate. Ctl, Control.

down-regulation of the anti-apoptotic gene $B c l-2(0.21 \pm 0.1$; $p \leq 0.01$ ). These data suggested that inhibition of aromatase may play an important role in inducing apoptosis.

\section{Discussion}

Previous studies have reported the beneficial therapeutic strategy in the use of cytotoxic drugs, which destroy cancer cells by the inhibition of aromatase and the induction of apoptosis in the cancer cells $(12,13)$. In this context, our study evaluated the anti-tumor effects of the new synthesized bis(4-hydroxy-2H-chromen-2-one) coumarin (4HC) on human breast cancer cells, in vitro. We aimed to investigate the effect of $4 \mathrm{HC}$ on the proliferation and apoptosis of MCF-7 breast cancer cells and non-cancerous cells MCF-10a as well. Moreover, the study focused on the impact of $4 \mathrm{HC}$ on the regulation of aromatase and apoptosis-related genes.
Obviously, our results showed an antitumor activity of 4HC with a significant inhibition of the proliferation of human breast cancer cells MCF-7 in a dose and time dependent manner. Significant cytotoxic effects were observed after $24 \mathrm{~h}$ of treatment at $50 \mu \mathrm{M}$. Previous studies have shown a similar antiproliferative activity related to the presence of hydroxyl group at position 4 against other cancer cell lines $(14,15)$. Even more interesting, we demonstrated the ability of $4 \mathrm{HC}$ to inhibit cell viability without significant cytotoxicity on hyperplastic non-cancerous cells. These data are in agreement with earlier reports demonstrating selectivity of coumarin (16) and especially 4HC toward K562 and the leukemic JURKAT cell lines (8).

Among the potential mechanisms that have proven effective for the treatment of cancer is the blockade of the cell cycle (17). In our study, cell cycle analysis revealed that $4 \mathrm{HC}$ caused arrest in the $\mathrm{G}_{2} / \mathrm{M}$ phase, in a concentration dependent manner, associated with a decrease in the $G_{1}$ 

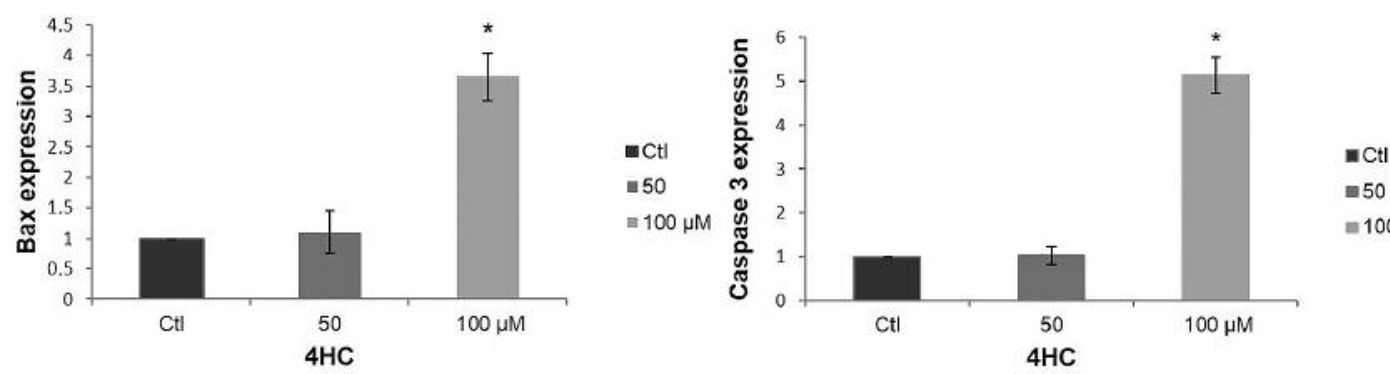

$=50$

$=100 \mu \mathrm{M}$
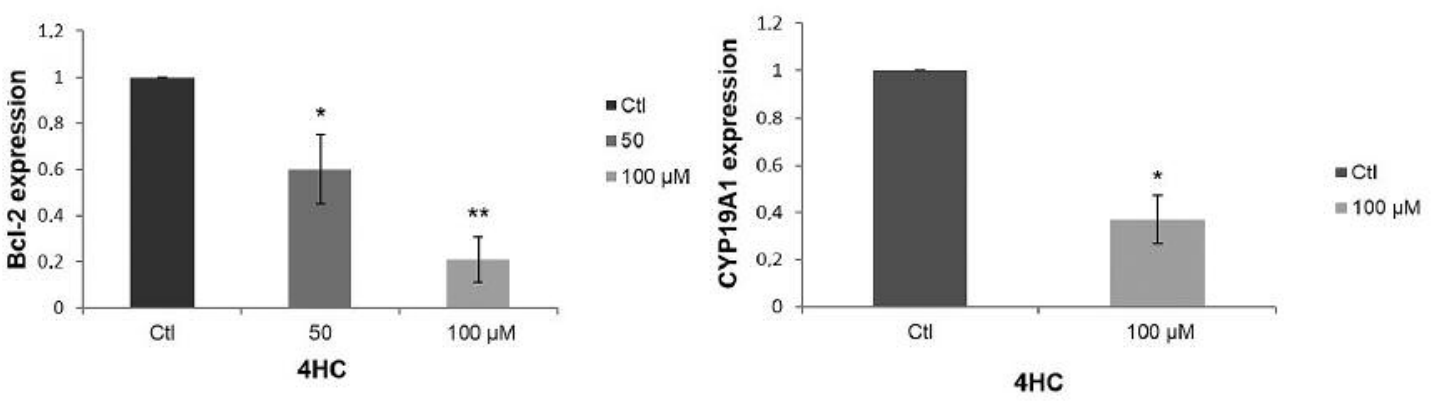

Figure 5. The relative expression of the pro-apoptotic Bax, and caspase 3 genes, the anti-apoptotic gene Bcl-2 and the aromatase gene CYP19A1 levels in $4 H C$-treated and control MCF-7 cells (for $72 \mathrm{~h}$ ) were analyzed using quantitative real-time reverse transcription polymerase chain reaction $(q R T-P C R) .{ }^{*} p \leq 0.05 ; * * \leq 0.01$, compared to the control group. Experiments were repeated in triplicate. Ctl, Control.

phase. Many previous studies have demonstrated the ability of coumarin derivatives to induce cell cycle arrest and apoptosis in other cancer cell lines (18-21), supporting our results. More specifically, similar effects on MCF-7 cell cycle progression were induced by the thiazolylpyrazolyl coumarin derivative $9 \mathrm{~d}(20)$, and a significant increase in the $\mathrm{G}_{2} / \mathrm{M}$-phase cell population followed by reduction of cells in $G_{1}$-phase was also observed in ovarian cancer cells after treatment with the coumarin derivative RKS262 (21).

Moreover, based on previous evidence about the essential role of the cell cycle in the regulation of cell growth and mediation of apoptosis (22-24), we decided to explore whether the cell cycle arrest induced by $4 \mathrm{HC}$ led to changes in apoptosis. Apoptosis is the process of programmed cell death and constitutes a target for variety of drugs (25-27). Referring to previous studies $(18,28)$, we used Annexin-V/PI staining to detect apoptosis and, a significant increase in apoptosis was observed in MCF-7 cells after treatment with $4 \mathrm{HC}$ for $72 \mathrm{~h}$.

Bax and $\mathrm{Bcl}-2$ proteins represent the most important effectors of apoptosis and play a pivotal role in the regulation of cell death $(29,30)$. Alteration in the ratio of $\mathrm{Bax} / \mathrm{Bcl} 2$ is a crucial factor in apoptosis induction $(31,32)$. A significant down-regulation of $B c l-2$ and an up-regulation of the Bax gene expressions after $4 \mathrm{HC}$ treatment reflect a decrease in the $\mathrm{Bcl}-2 / \mathrm{Bax}$ ratio which could result in the activation of the caspase apoptosis proteins (33). Caspases, like caspase 3, are cysteinyl aspartate-specific proteinases playing a critical role in apoptosis and provide a target for therapies (34). Our study results support these findings and demonstrated that $4 \mathrm{HC}$ induced overexpression of caspase-3 gene, which is required for regulation of apoptosis.

Based on all of the above, and in order to define the underlying mechanisms of $4 \mathrm{HC}$ apoptosis, we focused on the inhibition of aromatase. Aromatase inhibitors have been reported to block cell proliferation and promote signal transduction pathways of cell death (35). In addition, the detailed mechanism under which aromatase blocking induced cell cycle arrest, activation of caspases and promotion of apoptosis has already been defined (36). Ours results revealeed that $4 \mathrm{HC}$ has also anti-aromatase potency by inducing down-regulation of CYP19A1 gene expression, which could lead to the cell cycle arrest and promotion of apoptosis observed in MCF-7 cancer cells. These findings further support a previous report which demonstrated the aromatase inhibitor potential of coumarin derivatives in breast cancer cell lines (37).

In summary, our study demonstrated for the first time that 4HC selectively inhibited the proliferation of MCF-7 breast cancer cells and induced cell cycle arrest leading to the activation of apoptosis. Furthermore, our results suggested that down-regulation of aromatase gene may be a potential 
mechanism responsible for $4 \mathrm{HC}$-induced cell death, resulting in a decrease in Bcl-2, an increase in Bax, and caspase-3 gene expression. Based on these encouraging findings, the inhibition of aromatase activity using $4 \mathrm{HC}$ might be a promising strategy in breast cancer treatment.

\section{Conflicts of Interest}

The Authors declare that they have no known competing financial interests or personal relationships that could have appeared to influence the work reported in this paper.

\section{Authors' Contributions}

OT, AS and KB performed the chemical experiments, LHR, MV and $\mathrm{AB}$ performed the biological experiments. LHR, CD, MPV, LD and FCC analyzed the data and wrote the manuscript.

\section{Acknowledgements}

The Authors would like to thank Université Clermont Auvergne, INRA, UNH, Unité de Nutrition Humaine, CRNH Auvergne, the University of Aveiro, Fundação para a Ciência e a Tecnologia (Portugal), EU, QREN, FEDER, COMPETE and Scientific and Technical Research Center in Physico-Chemical Analysis (CRAPC) for allowing us the achievement of this work.

Funding: This work was financially supported by Université Clermont Auvergne, Equipe ECREIN (France) and the University of Aveiro (Portugal). Algeria's General Directorate for Scientific Research and Technological Development (DGRSDT) also made it contribution.

\section{References}

1 Ghoncheh M, Pournamdar Z and Salehiniya H: Incidence and mortality and epidemiology of breast cancer in the world. Asian Pac J Cancer Prev 17(S3): 43-46, 2016. PMID: 27165206. DOI: 10.7314/apjcp.2016.17.s3.43

2 Murray RDH, Mendez J and Brown SA: The natural coumarins: Occurrence, chemistry and biochemistry (Book). Plants, Cells and Environment 6(5): 435-436, 1982. DOI: 10.1111/1365 3040.ep11611630

3 Cassileth B, Yeung KS and Gubili J: Herbs and other botanicals in cancer patient care. Curr Treat Options Oncol 9(2-3): 109-116, 2008. PMID: 18612829. DOI: 10.1007/s11864-008-0061-5

4 Klenkar J and Molnar M: Natural and synthetic coumarins as potential anticancer agents. J Chem Pharm Res 7(7): 1223-1238, 2015.

5 Wang L, Peng Y, Shi K, Wang H, Lu J, Li Y and Ma C: Osthole inhibits proliferation of human breast cancer cells by inducing cell cycle arrest and apoptosis. J Biomed Res 29(2): 132-138, 2015. PMID: 25859268. DOI: 10.7555/JBR.27.20120115

6 Cheng JF, Chen M, Wallace D, Tith S, Arrhenius T, Kashiwagi $\mathrm{H}$, Ono Y, Ishikawa A, Sato H, Kozono T, Sato H and Nadzan AM. Discovery and structure-activity relationship of coumarin derivatives as TNF-alpha inhibitors. Bioorg Med Chem Lett 14(10): 2411-2415, 2004. PMID: 15109623. DOI: 10.1016/ j.bmcl.2004.03.022
7 Ballazhi L, Imeri F, Jashari A, Popovski E, Stojković G, Dimovski AJ, Mikhova B and Mladenovska K: Hydrazinyldienechroman-2,4-diones in inducing growth arrest and apoptosis in breast cancer cells: Synergism with doxorubicin and correlation with physicochemical properties. Acta Pharm 67(1): 35-52, 2017. PMID: 28231049. DOI: $10.1515 /$ acph-2017-0006

8 Talhi O, Schnekenburger M, Panning J, Pinto GCD, Fernandes JA, Paz FAA, Jacob C, Diederich M and Silva AMS: Bis(4hydroxy-2H-chromen-2-one): Synthesis and effects on leukemic cell lines proliferation and NF-jB regulation. Bioorg \& Med Chem 22(11): 3008-3015, 2014. PMID: 24775915. DOI: 10.1016/j.bmc.2014.03.046

9 Simstein R, Burow M, Parker A, Weldon C and Beckman B: Apoptosis, chemoresistance, and breast cancer: insights from the MCF-7 cell model system. Exp Biol Med 228(9): 995-1003, 2003. PMID: 14530507. DOI: $10.1177 / 153537020322800903$

10 Diel P, Smolnikar K and Michana H: The pure antiestrogen ZM 182,780 is more effective in the induction of apoptosis and down-regulation of BCL-2 than tamoxifen in MCF-7 cells. Breast Cancer Res Treat 58(2): 87-97, 1999. PMID: 10674872. DOI: $10.1023 / \mathrm{a}: 1006338123126$

11 Cho M, Karlsberg K, Zhou D and Yuan YC: Biochemical and biological characterization of a novel anti-aromatase coumarin derivative. J Biol Chem 279(46): 48071-48078, 2004. PMID: 15358790. DOI: $10.1074 /$ jbc.M406847200

12 Singh RK, Lange TS, Kim KK and Brard L: A coumarin derivative (RKS262) inhibits cell-cycle progression, causes proapoptotic signaling and cytotoxicity in ovarian cancer cells. Invest New Drugs 29(1): 63-72, 2011. PMID: 19865799. DOI: 10.1007/s 10637-009-9335-4

13 Pistritto G, Trisciuoglio D, Ceci, C, Garufi A and D' Orazi G: Apoptosis as anticancer mechanism: function and dysfunction of its modulators and targeted therapeutic strategies. Aging 8(4): 603-619, 2016. PMID: 27019364. DOI: 10.18632/aging. 100934

14 Ballazhi L, Popovski E, Jashari A, Imeri F, Ibrahimi I, Mikhova B and Mladenovska K: Potential antiproliferative effect of isoxazolo- and thiazolo coumarin derivatives on breast cancer mediated bone and lung metastases. Acta Pharm (65): 53-63, 2015. PMID: 25781704. DOI: 10.1515/acph-2015-0002

15 Jamier V, Marut W, Valente S, Chereau C, Chouzenoux S, Nicco C, Lemarechal H, Weill B, Kirsch G, Jacob C and Batteux F: Chalcone-coumarin derivatives as potential anti-cancer drugs: An in vitro and in vivo investigation. Anticancer Agents Med Chem (14): 963-74, 2014. PMID: 24372527.

16 Kawaii S, Tomono Y, Ogawa K, Sugiura M, Yano M, Yoshizawa $\mathrm{Y}$, Ito $\mathrm{C}$ and Furukawa $\mathrm{H}$ : Antiproliferative effect of isopentenylated coumarins on several cancer cell lines. Anticancer Res 21(3B): 1905-1911, 2001. PMID: 11497276.

17 McDonald ER and El-Deiry WS: Cell cycle control as a basis for cancer drug development. Int J Oncol 16(5): 871-957, 2000. PMID: 10762622.

18 Chuang JY, Huang YF, Lu HF, Ho HC, Yang JS, Li TM, Chang NW and Chung JG: Coumarin induces cell cycle arrest and apoptosis in human cervical cancer HeLa cells through a mitochondria- and caspase-3 dependent mechanism and NFkappaB down-regulation. In Vivo 21(6): 1003-1009, 2007. PMID: 18210747.

19 Musa MA, Badisa VL, Latinwo LM, Waryoba C and Ugochukwu $\mathrm{N}$ : In vitro cytotoxicity of benzopyranone 
derivatives with basic side chain against human lung cell lines. Anticancer Res 30(11): 4613-4617, 2010. PMID: 21115914.

20 Mohamed TK, Batran RZ, Elseginy SA, Ali MM and Mahmoud AE : Synthesis, anticancer effect and molecular modeling of new thiazolylpyrazolyl coumarin derivatives targeting VEGFR-2 kinase and inducing cell cycle arrest and apoptosis. Bioorg Chem 85: 253-273, 2019. PMID: 30641320. DOI: 10.1016/ j.bioorg.2018.12.040

21 Singh RK, Lange TS, Kim KK and Brard L: A coumarin derivative (RKS262) inhibits cell-cycle progression, causes proapoptotic signaling and cytotoxicity in ovarian cancer cells. Invest New Drugs 29(1): 63-72, 2011. PMID: 19865799. DOI: 10.1007/s10637-009-9335-4

22 Buolamwini JK: Cell cycle molecular targets in novel anticancer drug discovery. Curr Pharm Des 14(11): 379-392, 2000. PMID: 10788588. DOI: $10.2174 / 1381612003400948$

23 Hartwell LH and Kastan MB: Cell cycle control and cancer. Science 266(5192): 1821-1828, 1994. PMID: 7997877. DOI: $10.1126 /$ science. 7997877

24 Vermeulen K, Van Bockstaele DR and Berneman ZN: The cell cycle: A review of regulation, deregulation and therapeutic targets in cancer. Cell Prolif 36(3): 131-149, 2003. PMID: 12814430. 24. DOI: 10.1046/j.1365-2184.2003.00266.x

25 Venkatadri R, Muni T, Iyer AK, Yakisich JS and Azad N: Role of apoptosis-related miRNAs in resveratrol-induced breast cancer cell death. Cell Death Dis (7): e2104. 2016. PMID: 26890143. DOI: $10.1038 /$ cddis.2016.6

26 Strasser A, Cory S and Adams JM: Deciphering the rules of programmed cell death to improve therapy of cancer and other diseases. EMBO J 30(18): 3667-3683, 2011. PMID: 21863020. DOI: $10.1038 /$ emboj.2011.307

27 García MA, Carrasco E, Ramirez A, Jiménez G, Lopez-Ruiz E, Peran M, Picon M, Campos J, Boulaiz, H and Marchal JA: Apoptosis as a therapeutic target in cancer and cancer stem cells: Novel strategies and futures perspectives. In: Apoptosis and Medicine. Ntuli TM (ed.). IntechOpen. Chapter 6, 2012. DOI: $10.5772 / 48267$

28 Bisi A, Cappadone C, Rampa A, Farruggia G, Sargenti A, Belluti F, Di Martino RMC, Malucelli E, Meluzzi A, Iotti S and Gobbi S: Coumarin derivatives as potential antitumor agents: Growth inhibition, apoptosis induction and multidrug resistance reverting activity. Eur J Med Chem (127): 577-585, 2017. PMID: 28109950. DOI: 10.1016/j.ejmech.2017.01.020

29 Korsmeyer SJ, Shutter JR, Veis DJ, Merry DE and Oltvai ZN: Bcl-2/Bax: a rheostat that regulates an anti-oxidant pathway and cell death. Semin Cancer Biol 4(6): 327-332, 1993. PMID: 8142617.
30 Gibson LF, Fortney J, Magro G, Ericson SG, Lynch JP and Landreth KS: Regulation of BAX and BCL-2 expression in breast cancer cells by chemotherapy. Breast Cancer Res Treat 55(2): 107-117, 1999. PMID: 10481938. DOI: 10.1023/a: 1006175811676

31 Gonzalez de Aguilar JL, Gordon JW, René F, de Tapia M, LutzBucher B, Gaiddon C and Loeffler JP: Alteration of the Bcl$\mathrm{x} / \mathrm{Bax}$ ratio in a transgenic mouse model of amyotrophic lateral sclerosis: Evidence for the implication of the p53 signaling pathway. Neurobiol Dis 7(4): 406-415, 2000. PMID: 10964611. DOI: $10.1006 /$ nbdi.2000.0295

32 Sharifi S, Barar J, Hejazi MS and Samadi N: Doxorubicin changes Bax /Bcl-xL ratio, caspase- 8 and 9 in breast cancer cells. Adv Pharm Bull 5(3): 351-359, 2015. PMID: 26504757. DOI: $10.15171 / \mathrm{apb} .2015 .049$

33 Salakou S, Kardamakis D, Tsamandas AC, Zolota V, Apostolakis E, Tzelepi V, Papathanasopoulos P, Bonikos DS, Papapetropoulos $\mathrm{T}$, Petsas $\mathrm{T}$ and Dougenis D: Increased Bax/Bcl-2 ratio upregulates caspase- 3 and increases apoptosis in the thymus of patients with myasthenia gravis. In Vivo 21(1): 123-13, 2007. PMID: 17354625.

34 Yamabe K, Shimizu S, Ito T, Yoshioka Y, Nomura M, Narita M, Saito I, Kanegae Y and Matsuda H: Cancer gene therapy using a pro-apoptotic gene, caspase-3. Gene Ther 6(12): 1952-1959, 1999. PMID: 10637446. DOI: $10.1038 /$ sj.gt.3301041

35 Amaral C, Varela C, Borges M, Tavares da Silva E, Roleira FMF, Correia-da-Silva G and Teixeira N: Steroidal aromatase inhibitors inhibit growth of hormone-dependent breast cancer cells by inducing cell cycle arrest and apoptosis. Apoptosis 11(18): 14261436, 2013. PMID: 23842740. DOI: 10.1007/s10495-013-0879-6

36 Thiantanawat A, Long BJ and Brodie AM: Signaling pathways of apoptosis activated by aromatase inhibitors and antiestrogens. Cancer Res 63(22): 8037-8050, 2003. PMID:14633737.

37 Musa MA, Cooperwood JS and Khan MO: A review of coumarin derivatives in pharmacotherapy of breast cancer. Curr Med Chem 15(26): 2664-2679, 2008. PMID: 8991629. DOI: $10.2174 / 092986708786242877$
Received September 10, 2019

Revised October 11, 2019

Accepted October 16, 2019 